\title{
Tinjauan Hukum Platform Digital Sapardi_ID Berdasarkan Undang-Undang Nomor 8 Tahun 2016 Tentang Disabilitas
}

\author{
Yayang Nuraini Zulfiani ${ }^{1}$ \\ ${ }^{1}$ Fakultas Hukum, Pascasarjana Universitas Islam Negeri Sunan Gunung Djati. \\ Cimenerang, Kota Bandung, 40292 \\ Penulis untuk Korespondensi/Email: yayangnurainizulf@gmail.com
}

\begin{abstract}
The Republic of Indonesia is a country based on Pancasila and the 1945 Constitution of the Republic of Indonesia, meaning that the Indonesian people must always respect and uphold human dignity. With the enactment of Law Number 19 of 2011 concerning the Ratification of the Convention on the Rights of Persons with Disabilities, it certainly shows the commitment of the Government of Indonesia and all its people to respect, protect, and fulfill the rights of Persons with Disabilities which in the end is expected to be able to improve the welfare of Persons with Disabilities through the active participation of the community in ensuring the fulfillment of the rights of persons with disabilities in all aspects of life In the 4.0 revolution era, of course, it is important to always communicate and share information with persons with disabilities because the reach of the law and the government in the context of the welfare of persons with disabilities is very limited, active participation is needed the community to participate in understanding and assisting the special needs of people with disabilities, in the context of implementing and fulfilling the rights of people with disabilities that are more qualified, fair and prosperous, Digital Platform S apaardi ID is an educational media for the general public to understand people with disabilities so that people can learn to communicate and respect Persons with Disabilities as stated in Law Number 8 of 2016 concerning Persons with Disabilities, this research uses descriptive qualitative research methods with library sources, institutional surveys and independent surveys with the results that in its implementation this platform still does not reach many parties to actively participate and still needs program development and collaboration with various parties.
\end{abstract}

Keywords: Persons with Disabilities, Sapardi ID, Platform, Education

\begin{abstract}
Abstrak
Negara Republik Indonesia merupakan negara yang berdasarkan Pancasila dan UndangUndang Dasar Negara Republik Indonesia Tahun 1945, artinya masyarakat Indonesia harus senantiasa menghormati dan menjunjung tinggi harkat dan martabat manusia. Dengan disahkannya UndangUndang Nomor 19 Tahun 2011 tentang Pengesahan Convention on the Rights of Persons with Disabilities (Konvensi Hak-hak Penyandang Disabilitas) tentunya menunjukkan komitmen Pemerintah Indonesia serta seluruh masyarakatnya untuk menghormati, melindungi, dan memenuhi hak Penyandang Disabilitas yang pada akhirnya diharapkan dapat meningkatkan kesejahteraan Penyandang Disabilitas melalui partisipasi aktif masyarakat dalam menjamin pemenuhan hak penyandang disabilitas dalam segala aspek kehidupan. Pada era revolusi 4.0 tentunya penting untuk senantiasa berkomunikasi dan berbagi informasi terhadap penyandang disabilitas. Karena jangkauan hukum dan pemerintah dalam rangka mensejahterakan penyandang disabilitas sangatlah terbatas, perlu adanya partisipasi aktif masyarakat untuk ikut memahami dan membantu kebutuhan khusus penyandang disabilitas, dalam rangka pelaksanaan dan pemenuhan hak penyandang disabilitas yang lebih berkualitas, adil dan sejahtera. Platform Digital Sapardi_ID menjadi media edukatif bagi
\end{abstract}


masyarakat umum untuk memahami penyandang disabilitas sehingga masyarakat dapat belajar berkomunikasi dan menghargai Penyandang Disabilitas sebagaimana Undang-Undang Nomor 8 Tahun 2016 tentang Penyandang Disabilitas. Penelitian ini menggunakan metode penelitian kualitatif secara deskriptif dengan sumber kepustakaan, survey lembaga dan survey mandiri, dengan hasil bahwa dalam implementasinya platform ini masih kurang menjangkau banyak pihak untuk berpartisipasi aktif serta masih perlu pengembangan program dan kerjasama dengan berbagai pihak.

Kata Kunci: Penyandang Disabilitas, Sapardi_ID, Platform, Edukasi

\section{PENDAHULUAN}

Menurut Kepala Sub Direktorat Rehabilitasi Sosial Penyandang Disabilitas, Kementrian Sosial menunjukkan data sebanyak 21,84 juta jiwa atau jumlah penyandang disabilitas di Indonesia pada tahun 2015 mencapai 8,56\% dari penduduk Indonesia dimana setiap tahunnya terus bertambah (Kementrian Sosial Republik Indonesia, 2018) maka Indonesia sebagai negara hukum, tentunya setiap orang tanpa terkecuali berhak berkomunikasi dan mendapatkan akses informasi dengan mudah termasuk penyandang disabilitas sebagaimana Pasal 1 ayat (2) Undang-Undang Nomor 8 Tahun 2016 "Kesamaan Kesempatan adalah keadaan yang memberikan peluang dan/atau menyediakan akses kepada Penyandang Disabilitas untuk menyalurkan potensi dalam segala aspek penyelenggaraan negara dan masyarakat" oleh karena itu maka perlu langkah nyata untuk mengembangkan kesadaran masyarakat demi memahami kebutuhan khusus penyandang disabilitas, pada sisi lain, tidak banyak masyarakat yang dapat berkomunikasi dengan baik kepada penyandang disabilitas dikarenakan minimnya media edukatif sebagai sarana pembelajaran hal itu dapat dilihat pada Google, Instagram dan Youtube informasi pembelajaran mengenai penyandang disabilitas masih sedikit dibandingkan rumpun keilmuan lain oleh karena itu penulis beranggapan bahwa diperlukan pengenalan yang lebih masif agar informasi untuk berkomunikasi dengan penyandang disabilitas dan diskusi seputar karya sastra/seni ramah disabilitas menjadi lebih luas. Satu di antara peluangnya adalah dengan memaksimalkan sosialisasi melalui jaringan internet maupun diluar jaringan. Dalam rangka meningkatkan kompetensi dalam memahami atau berkomunikasi dengan pemustaka penyandang disabilitas tuna rungu, Pusat Pendidikan dan Pelatihan Perpustakaan
Nasional RI menyelenggarakan program pelatihan Bahasa Isyarat. Diklat ini diselenggarakan secara tatap muka pada 1 s.d 10 Maret 2021, bekerja sama dengan Lembaga Bahasa Universitas Indonesia (LB UI). Diklat Bahasa isyarat dibuka secara langsung oleh Kepala Perpustakaan Nasional, Drs. Muhammad Syarif Bando, MM (Pusdiklat Perpustakaan Nasional Republik Indonesia, 2021) Oleh karena itu dalam rangka memenuhi hak penyandang disabilitas sebagaimana termuat dalam Undang-Undang, Sapardi_id sebagai media informatif di Instagram digagas berdasarkan pada penghormatan terhadap martabat, partisipasi penuh masyarakat, aksesibilitas mencari informasi, berkomunikasi, dan merasa dapat dilibatkan dalam masyarakat yang diperkuat oleh Pasal 24 Undang-Undang Nomor 8 Tahun 2016 yang memuat hak untuk berbicara, berkomunikasi, dan menerima informasi bagi penyandang disabilitas serta dirinci meliputi hak memiliki kebebasan berekspresi dan berekspresi, menerima informasi dan berkomunikasi melalui media yang mudah diakses, menggunakan dan memelihara pilihan informasi dan komunikasi berupa bahasa isyarat, Braille, dan komunikasi tambahan dalam transaksi formal.

Dan hal ini juga ditegaskan dalam UndangUndang Nomor 39 Tahun 1999 tentang Hak Asasi Manusia, bahwa tidak boleh ada diskriminasi dalam masyarakat sehingga masyarakat mempunyai tanggungjawab penuh untuk menghormati hak Penyandang Disabilitas. Penyandang Disabilitas seringkali mengalami banyak tindakan diskriminasi yang berakibat fatal yaitu tidak terpenuhinya pelaksanaan hak-hak Penyandang Disabilitas yang dijamin dalam konstitusi. Tanpa partisipasi aktif masyarakat untuk ikut membantu penyandang disabilitas maka nilainilai dalam Undang-Undang tentunya sangat sulit untuk diwujudkan karena masih berpacu 
dalam keterbatasan interaksi dan hambatan lain yang ada di lingkungan, hambatan tersebut dapat berupa hambatan fisik, serta hambatan yang disebabkan oleh sikap dan masyarakat yang abai dan diskriminatif, padahal dengan peduli terhadap penyandang disabilitas justru akan memberikan manfaat. Selain implementasi secara hukum, analisis ini menelaah efektivitas Sapardi_id sebagai media edukatif masih perlu berbagai pengembangan dalam segi konten, kelanjutan program, kerjasama dan jangkauan berbagai pihak agar dapat menjadi media edukasi yang besar dan berpengaruh bagi khalayak banyak.

\section{METODE PENELITIAN}

Metode yang digunakan dalam penelitian ini adalah metode kualitatif dengan pendekatan hukum empiris. Artinya, analisis dalam penelitian ini menggunakan penyelidikan antara das sein dan das solen ketentuan hukum yang berlaku dan bagaimana sesungguhnya peristiwa aktual dalam lingkup penelitian hukum tentang pembentukan atau pelaksanaan ketentuan hukum normatif yang sebenarnya. Analisa hukum yang terjadi dalam penelitian ini dianalisis dengan tujuan untuk menemukan fakta dan data yang dibutuhkan secara detail, dan setelah mengumpulkan data yang peneliti butuhkan, maka analisis dilanjutkan untuk mengidentifikasi dan menyelesaikan masalah (Arikunto, 2012). Pendekatan ini dilaksanakan dengan cara meneliti bahan pustaka (primer) atau data sekunder (Soekanto \& Mamuji, 2003). Dalam penelitian ini, bahan pustaka yang digunakan adalah data-data yang berkaitan dengan pengelolaan platform edukasi digital dan hak penyandang disabilitas. Penelitian ini bersifat deskriptif analitis berfungsi untuk mendeskripsikan atau memberi gambaran terhadap objek yang diteliti melalui data atau sampel yang telah terkumpul sebagaimana adanya tanpa melakukan analisis dan membuat kesimpulan yang berlaku untuk umum (Sugiyono, 2009) penggunaan metode kualitatif dalam penelitian ini bertujuan untuk mengetahui implementasi platform Sapardi_id pada masyarakat, melihat kendala-kendala apa saja yang terjadi didalamnya dan kaitannya dengan penerapan hukum positif terkait penyandang disabilitas.

\section{HASIL DAN PEMBAHASAN}

Negara Republik Indonesia merupakan negara yang berdasarkan Pancasila dan Undang Undang Dasar Negara Republik Indonesia Tahun 1945, artinya masyarakat Indonesia harus senantiasa menghormati dan menjunjung tinggi harkat dan martabat manusia. Hak asasi manusia sebagai hak dasar yang secara kodrati melekat pada diri manusia bersifat universal, wajib untuk di hormati, harus dilindungi, dan sangat urgen untuk dipertahankan, sehingga Pelindungan dan hak asasi manusia terhadap kelompok rentan, khususnya Penyandang Disabilitas. Dengan disahkannya UndangUndang Nomor 19 Tahun 2011 tentang Pengesahan Convention on the Rights of Persons with Disabilities (Konvensi Hak-hak Penyandang Disabilitas) tentunya hal ini menunjukkan komitmen dan kesungguhan dari Pemerintah Indonesia serta seluruh masyarakatnya untuk menghormati, melindungi, dan memenuhi hak Penyandang Disabilitas yang pada akhirnya diharapkan dapat meningkatkan kesejahteraan Penyandang Disabilitas, meskipun pemerintah telah mengatur segala kebutuhan penyandang disabilitas sebagaimana Pasal 94, 122, 123 dan 124 yang berbunyi :

Pasal 94 "Pemberdayaan sosial sebagaimana dimaksud dalam Pasal 91 dilakukan oleh Pemerintah dan Pemerintah Daerah melalui: peningkatan kemauan dan kemampuan; penggalian potensi dan sumber daya; penggalian nilai dasar;

pemberian akses; dan/atau pemberian bantuan usaha.

Pemberdayaan sosial sebagaimana dimaksud pada ayat (1) diberikan dalam bentuk: diagnosis dan pemberian motivasi; pelatihan dan pendampingan; pemberian stimulan; peningkatan akses pemasaran hasil usaha; penguatan kelembagaan dan kemitraan; dan bimbingan lanjut."

Pasal 122 "Pemerintah dan Pemerintah Daerah wajib mengakui, menerima, dan memfasilitasi komunikasi Penyandang Disabilitas dengan menggunakan cara tertentu. Komunikasi dengan menggunakan cara tertentu sebagaimana dimaksud pada ayat (1) dilakukan dengan cara, alat, dan bentuk lainnya yang dapat dijangkau sesuai dengan 
pilihan Penyandang Disabilitas dalam berinteraksi."

Pasal 123 "Pemerintah dan Pemerintah Daerah wajib menjamin akses atas informasi untuk Penyandang Disabilitas. Akses atas informasi untuk Penyandang Disabilitas sebagaimana dimaksud pada ayat (1) dalam bentuk audio dan visual."

Pasal 124 "Pemerintah dan Pemerintah Daerah wajib menyediakan informasi dalam bentuk yang dapat dijangkau dan dipahami sesuai dengan keragaman disabilitas dan kondisi tempat tinggalnya.

Informasi sebagaimana dimaksud pada ayat (1) didapatkan secara tepat waktu dan tanpa biaya tambahan."

Namun justru peran aktif masyarakat dan generasi muda yang sangat mempengaruhi kesejahteraan penyandang disabilitas, karena jangkauan hukum dan pemerintah tidak akan berhasil tanpa gerakan nyata oleh masyarakatnya itu sendiri, terlebih generasi muda merupakan agent of change yang justru memiliki berbagai ide yang baru dan dapat mengikuti kebutuhan serta perkembangan zaman. Sehingga untuk mewujudkannya perlu partisipasi aktif masyarakat dalam menjamin pemenuhan hak penyandang disabilitas dalam segala aspek kehidupan seperti pendidikan, kesehatan, pekerjaan, politik dan pemerintahan, kebudayaan dan kepariwisataan, serta pemanfaatan teknologi, informasi, dan komunikasi maka dibentuklah Sapardi_id sebagai Platform digital yang menjadi media edukatif dan diskusi terkait kesejahteraan penyandang disabilitas, Jangkauan hukum dan pemerintah dalam rangka mensejahterakan penyandang disabilitas sangatlah terbatas, platform Sapardi_id dalam sosial media Instagram merupakan partisipasi aktif masyarakat sebagai insan yang taat hukum untuk ikut memahami dan membantu kebutuhan khusus penyandang disabilitas. Penyelenggaraan dan pemenuhan hak penyandang disabilitas bertujuan untuk mencapai taraf hidup penyandang disabilitas yang lebih berkualitas, merata, kaya lahir dan batin, serta bermartabat. Selain itu, penegakan dan penegakan hak dimaksudkan untuk melindungi penyandang disabilitas dari kelalaian, eksploitasi, pelecehan, segala tindakan diskriminatif dan pelanggaran hak asasi manusia, sebagaimana diatur dalam hukum positif Indonesia, hal itu sejalan sebagaiamana yang dikemukakan oleh Phieter Angdika dari Laboratorium Riset Bahasa Isyarat Yogyakarta yang menjelaskan mengenai manfaat bahasa isyarat bagi orang dengar "Manfaat menggunakan bahasa isyarat tidak hanya untuk Tuli saja, ada juga banyak manfaat bahasa isyarat bagi orang dengar. Yang pertana, dengan mampu berbahasa isyarat, orang dengar dapat membantu orang-orang Tuli di sekitar kita, bisa menjadi penyambung lidah dan menjadi juru bahasa isyarat, menambah pengalaman dan teman baru, meningkatkan pemakai Bisindo yang masih sangat minim, dan turut mendukung perjuangan teman-teman Tuli di sekitar kita" (Phieter Angdika, 2020) pernyataan tersebut dilandasi pula oleh Hak Hidup Secara Mandiri dan Dilibatkan dalam Masyarakat sebagaimana Pasal 23 Undang Undang Nomor 8 Tahun 2016 Tentang Disabilitas yaitu :

"Hak hidup secara mandiri dan dilibatkan dalam masyarakat untuk Penyandang Disabilitas meliputi hak:

mobilitas pribadi dengan penyediaan Alat Bantu dan kemudahan untuk mendapatkan akses;

mendapatkan kesempatan untuk hidup mandiri di tengah masyarakat;

mendapatkan pelatihan dan pendampingan untuk hidup secara mandiri;

menentukan sendiri atau memperoleh bantuan dari Pemerintah dan Pemerintah Daerah untuk menetapkan tempat tinggal dan/atau pengasuhan keluarga atau keluarga pengganti; mendapatkan akses ke berbagai pelayanan, baik yang diberikan di dalam rumah, di tempat permukiman, maupun dalam masyarakat; dan mendapatkan akomodasi yang wajar untuk berperan serta dalam kehidupan bermasyarakat."

Selanjutnya, Sapardi_id mengupayakan Hak Bebas dari Diskriminasi, Penelantaran, Penyiksaan, dan Eksploitasi Pasal 26:

"Hak bebas dari Diskriminasi, penelantaran, penyiksaan, dan eksploitasi untuk Penyandang Disabilitas meliputi hak bersosialisasi dan berinteraksi dalam kehidupan berkeluarga, bermasyarakat, dan bernegara tanpa rasa takut; dan mendapatkan Pelindungan dari 
segala bentuk kekerasan fisik, psikis, ekonomi, dan seksual."

Meningkatkan kesejahteraan penyandang disabilitas adalah tugas seluruh masyarakat, maka adalah kewajiban bagi kita untuk memahami penyandang disabilitas minimal tahu dan menghormati cara berkomunikasinya, Sapardi_id mencoba mewujudkan hal ini dan mencoba mewujudkan nilai-nilai dalam peraturan lain yang menunjang seperti:

1. Undang Undang Dasar 1945, terdapat 10 pasal, yaitu Pasal 28A sampai Pasal 28J, yang mencakup:

Pasal 28C (1) Setiap orang berhak mengembangkan diri melalui pemenuhan kebutuhan dasarnya, berhak mendapat pendidikan dan memperoleh manfaat dari ilmu pengetahuan dan teknologi, seni dan budaya, demi meningkatkan kualitas hidupnya dan demi kesejahteraan umat manusia**)

(2) Setiap orang berhak untuk memajukan dirinya dalam memperjuangkan haknya secara kolektif untuk membangun masyarakat, bangsa dan negaranya**)

Pasal 28D (1) Setiap orang berhak atas pengakuan, jaminan, perlindungan, dan kepastian hukum yang adil serta perlakuan yang sama dihadapan hukum**)

Pasal 28F Setiap orang berhak untuk berkomunikasi dan memperoleh informasi untuk mengembangkan pribadi dan lingkungan sosialnya, serta berhak untuk mencari, memperoleh, memiliki, menyimpan, mengolah, dan menyampaikan informasi dengan menggunakan segala jenis saluran yang tersedia**)

Pasal 28G (1) Setiap orang berhak atas perlindungan diri pribadi, keluarga, kehormatan, martabat, dan harta benda yang di bawah kekuasaannya, serta berhak atas rasa aman dan perlindungan dari ancaman ketakutan untuk berbuat atau tidak berbuat sesuatu yang merupakan hak asasi**)

Analisisnya, Sapardi_id mencoba mengembangkan pendidikan melalui ilmu pengetahuan dan teknologi seni dan budaya, demi meningkatkan kualitas hidup penyandang disabilitas melalui konten pengenalan dasar jenis penyandang disabilitas dan cara-cara memahami penyandang disabilitas, apabila masyarakat memahami maka diharapkan akan saling menghormati hak-hak antar manusia termasuk dalam bersosialisasi dan berkomunikasi, sehingga tujuan jangka panjangnya sebagaimana pasal $28 \mathrm{H}, 28 \mathrm{I}$ dan 28J yang berbunyi :

Pasal $28 H$ (1) Setiap orang berhak hidup sejahtera lahir dan batin, bertempat tinggal, dan mendapatkan lingkungan hidup yang baik dan sehat serta berhak memperoleh pelayanan kesehatan**)

(2) Setiap orang berhak mendapat kemudahan dan perlakuan khusus untuk memperoleh kesempatan dan manfaat yang sama guna mencapai persamaan dan keadilan**)

(3) Setiap orang berhak atas jaminan sosial yang memungkinkan pengembangan dirinya secara utuh sebagai manusia yang bermartabat**)

(4) Setiap orang berhak mempunyai hak milik pribadi dan hak milik tersebut tidak boleh diambil alih secara sewenangwenang oleh siapapun**)

Pasal $28 I$ (1) Hak untuk hidup, hak untuk tidak disiksa, hak untuk kemerdekaan pikiran dan hati nurani, hak beragama, hak untuk tidak diperbudak, hak untuk diakui sebagai pribadi dihadapan hukum, dan hak untuk tidak dituntut atas dasar hukum yang berlaku surut adalah hak asasi manusia yang tidak dapat dikurangi dalam keadaan apapun**)

(2) Setiap orang bebas dari perlakuan yang bersifat diskriminatif atas dasar apapun dan berhak mendapatkan perlindungan terhadap perlakuan yang bersifat diskriminatif itu**)

(3) Identitas budaya dan hak masyarakat tradisional dihormati selaras dengan perkembangan zaman dan peradaban**) (4) Perlindungan, pemajuan, penegakan, dan pemenuhan hak asasi manusia adalah tanggung jawab negara, terutama pemerintah.**)

(5) Untuk menegakkan dan melindungi hak asasi manusia sesuai dengan prinsip negara hukum yang demokratis, maka pelaksanaan hak asasi manusia dijamin, 
diatur, dan dituangkan dalam peraturan perundang-undangan $* *$ )

Pasal 28J (1) Setiap orang wajib menghormati hak asasi manusia orang lain dalam tertib kehidupan bermasyarakat, berbangsa, dan bernegara**)

(2) Dalam menjalankan hak dan kebebasannya, setiap orang wajib tunduk kepada pembatasan yang ditetapkan dengan undang-undang dengan maksud semata-mata untuk menjamin pengakuan serta penghormatan atas hak dan kebebasan orang lain dan untuk memenuhi tuntutan yang adil sesuai dengan pertimbangan moral, nilai-nilai agama, keamanan, dan ketertiban umum dalam suatu masyarakat demokratis**)

Hal ini diperkuat pula oleh Putusan MK Nomor 10-17-23/PUU-VII/2009; Putusan MK Nomor 143/PUU-VII/2009; dan Putusan MK No. 16/PUU-VIII/2010. Dalam ketiga Putusan itu, MK menyatakan bahwa:

"Hak konstitusional dalam Pasal $28 H$ ayat (2) UUD 1945 adalah jaminan konstitusional terhadap mereka yang mengalami peminggiran, ketertinggalan, pengucilan, pembatasan, pembedaan, kesenjangan partisipasi dalam politik dan kehidupan publik yang bersumber dari ketimpangan struktural dan sosio-kultural masyarakat secara terus menerus (diskriminasi), baik formal maupun informal, dalam lingkup publik maupun privat atau yang dikenal dengan affirmative action."

Berdasarkan pasal-pasal diatas, keseluruhan ketentuan itu dapat dibagi menjadi dua jenis, yaitu perlindungan HAM khusus bagi warga negara dan perlindungan HAM bagi setiap orang, yang berarti tidak hanya warga negara Indonesia. Dalam dua jenis kelompok itu tidak ada lagi klasifikasi lain, yang berarti, baik dalam jenis perlindungan terhadap warga negara atau terhadap setiap orang, kelompok penyandang disabilitas masuk di dalam keduanya hal ini diperkuat oleh UndangUndang Nomor 29 Tahun 1999 tentang Pengesahan International Convention on the Elimination of All Forms of Racial Discrimination 1965 (Konvensi Internasional tentang Penghapusan Segala Bentuk
Diskriminasi Rasial 1965), Undang Undang Nomor 39 Tahun 1999 tentang Hak Asasi Manusia dan lebih jelasnya dijelaskan dalam Undang-Undang Nomor 11 Tahun 2009 tentang Kesejahteraan Sosial Pasal 16 (1) yang berbunyi:

Advokasi sosial dimaksudkan untuk melindungi dan membela seseorang, keluarga, kelompok, dan/atau masyarakat yang dilanggar haknya.

(2) Advokasi sosial sebagaimana dimaksud pada ayat (1) diberikan dalam bentuk penyadaran hak dan kewajiban, pembelaan, dan pemenuhan hak."

Pasal 38(1) Masyarakat mempunyai kesempatan yang seluasluasnya untuk berperan dalam penyelenggaraan kesejahteraan sosial.

(2) Peran sebagaimana dimaksud pada ayat (1) dapat dilakukan oleh:

a. perseorangan;

b. keluarga;

c. organisasi keagamaan;

d. organisasi sosial kemasyarakatan;

e. lembaga swadaya masyarakat;

f. organisasi profesi;

g. badan usaha;

h. lembaga kesejahteraan sosial; dan

i. lembaga kesejahteraan sosial asing.

(3) Peran sebagaimana dimaksud pada ayat (2) dilakukan untuk mendukung keberhasilan penyelenggaraan kesejahteraan sosial."

Maka dalam ayat tersebut setiap orang atau komunitas seperti Sapardi_id berhak untuk mendukung keberhasilan penyelenggaraan kesejahteraan sosial, termasuk dalam rangka meningkatkan kesejahteraan penyandang disabilitas, meskipun Sapardi_id masih berupa platform mikro dengan followers Instagram dibawah 1000, namun jangkauannya diperkuat dengan diskusi via Zoom dan Google meet serta sosialisasi secara langsung bersama berbagai stakeholder terkait sejalan dengan tujuan Convention on the Rights of Persons with Disabilities (CRPD), yang sudah diratifikasi melalui Undang Undang Nomor 19 Tahun 2011. Dengan demikian, adalah hal yang sangat penting bagi masyarakat untuk memahami dan tahu cara berkomunikasi dengan Penyandang Disabilitas karena Penyandang Disabilitas 
berhak untuk bebas untuk merealisasikan hak yang termuat dalam konvensi maupun undangundang terutama dalam Pasal 5 UndangUndang Nomor 8 Tahun 2016 yang berbunyi:

"Penyandang Disabilitas memiliki hak: hidup; bebas dari stigma; privasi; keadilan dan perlindungan hukum; pendidikan; pekerjaan, kewirausahaan, dan koperasi; kesehatan; politik; keagamaan; keolahragaan; kebudayaan dan pariwisata; kesejahteraan sosial; Aksesibilitas; Pelayanan Publik; Pelindungan dari bencana; habilitasi dan rehabilitasi; Konsesi; pendataan; hidup secara mandiri dan dilibatkan dalam masyarakat; berekspresi, berkomunikasi, dan memperoleh informasi; berpindah tempat dan kewarganegaraan; dan bebas dari tindakan Diskriminasi, penelantaran, penyiksaan, dan eksploitasi."

Selanjutnya penulis membuat survey online (Gform) yang telah diisi oleh 300 responden rentang usia 17-45 tahun dimana hasilnya menunjukkan bahwa hanya $30 \%$ responden yang mengerti cara berkomunikasi dengan penyandang disabilitas, baik dengan penyandang disabilitas sensorik, fisik, intelektual dan mental, hanya sekitar $20 \%$ responden yang mengetahui bahasa khusus penyandang disabilitas sensorik (bisindo/sibi/braille). Tentunya hal ini mendesak generasi Milenial sebagai agen perubahan agar mengambil langkah-langkah konkrit untuk mewujudkan masyarakat Indonesia yang lebih inklusif sehingga penyandang disabilitas dapat menikmati hak asasi manusia sepenuhnya dan berkontribusi sebesar-besarnya kepada masyarakat, salah satu caranya dengan memberikan edukasi yang mudah dan praktis terkait kebutuhan khusus disabilitas, teknologi dapat menjadi media yang efektif dalam upaya edukasi mengenai kebutuhan khusus penyandang disabilitas hal ini diperkuat oleh pendapat Allright (Allaright, 1984) yang mengemukakan bahwa "Interaksi merupakan landasan yang sangat penting dalam proses pemerolehan bahasa". Penulis melalui "Sapardi" (Sapa dan Pahami Disabilitas) mencoba menjadi solusi edukatif untuk belajar memahami penyandang disabilitas Mengingat sulit ditemuinya teknologi pendukung yang dapat menjadi panduan masyarakat luas untuk belajar berkomunikasi dengan penyandang disabilitas, maka ini sesuai dengan Pasal 2 Undang-Undang Nomor 8 Tahun 2016 yaitu:
"Pelaksanaan dan Pemenuhan hak Penyandang Disabilitas berasaskan: Penghormatan terhadap martabat; otonomi individu; tanpa Diskriminasi; partisipasi penuh; keragaman manusia dan kemanusiaan; Kesamaan Kesempatan; kesetaraan; Aksesibilitas; kapasitas yang terus berkembang dan identitas anak; inklusif; dan perlakuan khusus dan Pelindungan lebih."

Pelaksanaan Sapardi_Id yang bertujuan untuk menjaga Hak Berekspresi, Berkomunikasi,dan Memperoleh Informasi bagi penyandang disabilitas sejalan dengan Pasal 24 UndangUndang Nomor 8 Tahun 2016 yaitu

"Hak berekspresi, berkomunikasi, dan memperoleh informasi untuk Penyandang Disabilitas meliputi hak:

memiliki kebebasan berekspresi dan berpendapat;

mendapatkan informasi dan berkomunikasi melalui media yang mudah diakses; dan menggunakan dan memperoleh fasilitas informasi dan komunikasi berupa bahasa isyarat, braille, dan komunikasi augmentatif dalam interaksi resmi"

Dalam pelaksanaannya Sapardi id telah melaksanakan program memberikan informasi edukatif tentang cara berkomunikasi dengan penyandang disabilitas, lengkap dengan ilustrasi dan tips melalui Instagram Sapardi_id dengan tujuan mengajak generasi Milenial dan Zilenial untuk peduli dan mampu berkomunikasi (secara sederhana) dengan penyandang disabilitas, mengenalkan pengertian, jenis dan tips untuk berkomunikasi dengan penyandang disabilitas tertentu dengan media yang mudah diakses dan menarik (Instagram, Zoom dan Google Meet), mengajak generasi Milenial maupun generasi Zilenial agar senantiasa membuat karya sastra maupun seni yang ramah disabilitas (mencantumkan takarir), merangkul penyandang disabilitas agar lebih mudah berkomunikasi sehingga lebih aktif bersosialisasi di masyarakat, dukungan serta bentuk rasa menghargai antar sesama manusia sebagaimana Pasal 3 Undang-Undang Nomor 8 Tahun 2016 Tentang Disabilitas :

"Pelaksanaan dan Pemenuhan hak Penyandang Disabilitas bertujuan: 
mewujudkan Penghormatan, pemajuan, Pelindungan, dan Pemenuhan hak asasi manusia serta kebebasan dasar Penyandang Disabilitas secara penuh dan setara;

menjamin upaya Penghormatan, pemajuan, Pelindungan, dan Pemenuhan hak sebagai martabat yang melekat pada diri Penyandang Disabilitas;

mewujudkan taraf kehidupan Penyandang Disabilitas yang lebih berkualitas, adil, sejahtera lahir dan batin, mandiri, serta bermartabat;

melindungi Penyandang Disabilitas dari penelantaran dan eksploitasi, pelecehan dan segala tindakan diskriminatif, serta pelanggaran hak asasi manusia; dan

memastikan pelaksanaan upaya Penghormatan, pemajuan, Pelindungan, dan Pemenuhan hak Penyandang Disabilitas untuk mengembangkan diri serta mendayagunakan seluruh kemampuan sesuai bakat dan minat yang dimilikinya untuk menikmati, berperan serta berkontribusi secara optimal, aman, leluasa, dan bermartabat dalam segala aspek kehidupan berbangsa, bernegara, dan bermasyarakat."

Apabila secara hukum platform ini sudah cukup membantu mewujudkan cita-cita perundang-undangan namun sebaiknya apabila sudah menjadi komunitas yang besar maka diharapkan dapat mendaftarkan komunitasnya agar sah secara hukum, kekurangan lainnya yaitu pada proses penyebaran informasi melalui Instagram masih dirasa kurang karena hanya mendapat 200 followers dalam bulan pertama bahkan semakin menurun karena informasi kegiatan (webinar) yang semakin berkurang oleh karena itu perlu menelaah teori Manajemen Media Massa sebagaimana dalam menurut Ahli yaitu Handoko (Handoko, 2012) menyimpulkan bahwa pada dasarnya manajemen media masa ini didefinisikan sebagai cara kerja untuk menarik orang yang menentukkan, menginterpretasikan dan mencapai tujuan-tujuan organisasi dengan pelaksanaan fungsi-fungsi manajemen. Manajemen media adalah ilmu yang mempelajari bagaimana pengelolaan media dengan prinsip-prinsip dan seluruh proses manajemennya dilakukan, seperti media sebagai industri yang sifatnya komersial maupun sosial dan media sebagai institusi komesrsial maupun institusi sosial (Fajar, 2017), selanjutnya memperhatikan teori menurut Tommy Suprapto setiap kegiatan penyebaran informasi di Instagram perlu dikaitkan dengan pola manajemen yang pada umumnya dikaitkan dengan aktivitas perencanaan, pengorganisasian, pengendalian, penempatan, pengarahan, pemotivasian, komunikasi, dan pengambilan keputusan oleh setiap organisasi kemudian barulah mencapai tingkat keefektifan kegiatan komunikasi termasuk pencarian, pengumpulan, pemrosesan, dan penyaluran informasi arus balik (Sikula, 2015), sehingga untuk mengatasi hambatan dalam penyebaran informasi dalam media sosial, penulis menggagas untuk membuat sebuah program yang dapat membantu masyarakat untuk mengetahui informasi seputar penyandang disabilitas melalui dua kegiatan, yakni program daring dan program luring. Proses pencarian informasi dalam jaringan tentang cara berkomunikasi dengan penyandang disabilitas dilakukan Generasi Milenial dan Zilenial melalui Instagram @Sapardi_ID, Dalam 1 akun Instagram terdiri atas:

1.Postingan informasi

2.Postingan tips berkomunikasi dengan penyandang disabilitas

3.Diskusi seputar kebahasaan dan karya sastra/seni ramah disabilitas, @ Sapardi_ID seringkali mengadakan diskusi dalam jaringan melalui sila Instagram dua kali bersama Duta Generasi Berencana Kabupaten Bandung Barat (Fiqih) dan Bersama Duta Bahasa Jawa Barat (Annisa) kemudian disusul diskusi dalam Google meet dan Zoom untuk membahas pentingnya menciptakan karya sastra maupun karya seni yang ramah disabilitas salah satunya dengan mengedepankan isu kebahasaan isyarat/takarir hal ini dilaksanakan dengan cara memperkenalkan Sapardi untuk memahami penyandang disabilitas dalam sila Instagram pribadi dan @Sapardi_ID disaksikan oleh pengikut Instagram Sapardi_id dan Yayangnz dengan 40 orang penonton kemudian disusul oleh Diskusi "Yuk belajar hal baru, Tebarkan kebaikan!" (diskusi pertama, Karya sastra dan Karya seni yang ramah disabilitas) Dihadiri oleh remaja Kota Cimahi, Kabupaten Bandung dan Kabupaten Sumedang melalui google meet selanjutnya kembali diadakan diskusi "Yuk belajar hal baru, Tebarkan kebaikan! (diskusi kedua, Terjemahan karya sastra anak bangsa baik budaya daerah maupun subculture dengan penyesuaian melalui bahasa 
isyarat/braille/podcast) Dihadiri oleh remaja Kota Cimahi, Kabupaten Bandung dan Kabupaten Sumedang melalui google meet" dan ketiga kalinya diadakan diskusi "Yuk belajar hal baru, Tebarkan kebaikan!" (diskusi ketiga, Internasionalisasi Sastra Indonesia tanpa melupakan Takarir agar sahabat disabilitas dapat menikmatinya) Dihadiri oleh remaja Jawa Barat dan Jabodetabek melalui google meet, selanjutnya Sapardi_id kembali mengembangkan diskusi mengenai Keadilan untuk berkomunikasi dan mendapatkan informasi dibuka untuk umum via zoom (mengedepankan aspek penambahan Takarir dalam karya digital agar dapat dinikmati sahabat disabilitas) dan terakhir diadakan diskusi mengenai Pentingnya memahami penyandang disabilitas ditinjau dalam aspek hukum dalam Zoom bersama unit kegiatan mahasiswa studi hukum Fakultas Hukum Universitas Padjadjaran meskipun program Sapardi ini diharapkan mampu memberikan dampak yang luas dalam rangka memberikan edukasi tentang cara berkomunikasi dengan penyandang disabilitas, namun kurangnya kerjasama dengan berbagai pihak membuat minat masyarakat semakin berkurang untuk belajar, dalam langkah ini seharusnya diskusi merangkul stakeholder dari Yayasan, Pemerintah maupun Influencer sebagai daya tarik diskusi sebagaimana platform digital lain terkait edukasi bisindo dan peduli penyandang disabilitas yang seringkali bekerjasama dengan Yayasan, Pemerintah maupun Influencer.

\section{Video edukatif}

Sehingga, untuk mengembangkan kegiatan dalam jaringan yang kurang mendapat respon masyarakat, maka selain berbasis dalam jaringan, program Sapardi juga dilaksanakan secara luar jaringan. Kegiatan luar jaringan yang dilakukan berupa sosialisasi kepada organisasi remaja, sekolah hingga sarana kesehatan strategis karena bersinggungan langsung dengan generasi Milenial, Zilenial bahkan penyandang disabilitas itu sendiri, Selanjutnya, target utama program Sapardi khususnya adalah Generasi Milenial dan Zilenial, oleh karena itu terjun langsung dalam masyarakat adalah hal penting yang harus dilaksanakan, program luar jaringan pun menjadi sarana bagi penulis untuk mengetahui tingkat kepedulian dan pengetahuan masyarakat secara langsung dan dapat menjadi tolak ukur untuk mengambil langkah besar selanjutnya yang lebih tepat sasaran dan berdampak nyata. Proses pencarian informasi dalam jaringan tentang cara berkomunikasi dengan penyandang disabilitas dilakukan Generasi Milenial dan Zilenial melalui Instagram @Sapardi_ID, sebaliknya dalam proses penyebaran informasi diluar jaringan dilakukan dengan sosialisasi terhadap organisasi maupun instansi strategis yang dekat dengan Generasi Milenial dan Zilenial Selanjutnya, @Sapardi_ID seringkali mengadakan diskusi dalam jaringan melalui sila Instagram, Google meet dan Zoom untuk membahas pentingnya menciptakan karya sastra maupun karya seni yang ramah disabilitas salah satunya dengan mengedepankan isu kebahasaan isyarat/takarir sehingga program Sapardi ini diharapkan mampu memberikan dampak yang luas dalam rangka memberikan edukasi tentang cara berkomunikasi dengan penyandang disabilitas, yang pada akhirnya akan menghilangkan stigma miring dari masyarakat terhadap penyandang disabilitas dan penyandang disabilitas dapat merasa lebih dirangkul untuk bersosialisasi dengan masyarakat luas. Setelah memberikan edukasi berupa postingan berisi penjelasan, tips, video edukatif selanjutnya Sapardi membuka Diskusi seputar kebahasaan dan karya sastra/seni ramah disabilitas, @Sapardi_ID seringkali mengadakan diskusi dalam jaringan melalui sila Instagram, Google meet dan Zoom untuk membahas pentingnya menciptakan karya sastra maupun karya seni yang ramah disabilitas salah satunya dengan mengedepankan isu kebahasaan isyarat/takarir sehingga program Sapardi ini diharapkan mampu memberikan dampak yang luas dalam rangka memberikan edukasi tentang cara berkomunikasi dengan penyandang disabilitas, yang pada akhirnya akan menghilangkan stigma miring dari masyarakat terhadap penyandang disabilitas dan penyandang disabilitas dapat merasa lebih dirangkul untuk bersosialisasi dengan masyarakat luas, kegiatan yang telah dilaksanakan yaitu Sosialisasi kepada Guru TK-Plus Kabupaten Bandung Barat dengan tujuan pemahaman mengenai sahabat disabilitas dapat ditanamkan sejak dini (generasi X kepada Zilenial dan Alpha), Sosialisasi kepada pegawai PT. Kahatex Kota Cimahi dengan tujuan pengenalan cara berkomunikasi dengan penyandang disabilitas ditempat kerja (generasi Milenial dan generasi $\mathrm{X}$ ), Sosialisasi kepada tenaga kesehatan 
Puskesmas Kabupaten Bandung dengan tujuan efektivitas berkomunikasi dengan penyandang disabilitas ditempat umum ruang publik (Lintas generasi), Sosialisasi di tempat mengaji (Taman Pengajian Al-Quran) dengan tujuan pemahaman mengenai sahabat disabilitas dapat ditanamkan sejak dini (generasi Zilenial dan Alpha) dan Sosialisasi Bersama Kang Fiqih Pusat Informasi dan Konseling Remaja Kabupaten Bandung Barat dengan tujuan memperkenalkan Sapardi pada generasi Milenial, mengapa Sapardi_id bekerjasama dengan stakeholder tersebut karena dianggap dapat menunjang hak aksesibilitas penyandang disabilitas dalam bidang kesehatan, pendidikan dan kepemudaan, bahkan merambah pada pegawai sebuah industri agar menjangkau kesadaran masyarakat terkait hak-hak penyandang disabilitas terutama hal ini sejalan dengan Hak Aksesibilitas Pasal 18 UndangUndang Nomor 8 Tahun 2016 Tentang Disabilitas yang berbunyi :

"Hak Aksesibilitas untuk Penyandang Disabilitas meliputi hak:

mendapatkan Aksesibilitas untuk memanfaatkan fasilitas publik; dan mendapatkan Akomodasi yang Layak sebagai bentuk Aksesibilitas bagi individu"

\section{KESIMPULAN}

Melalui Sapardi id masyarakat dapat belajar memahami dan berkomunikasi dengan penyandang disabilitas, hal ini sudah dapat mewujudkan banyak nilai-nilai luhur dan implementasi perundang-undangan terutama dalam rangka kebebasan berkomunikasi dan membantu pemerintah untuk mewujudkan kesejahteraan sosial, namun seharusnya Sapardi_id bisa berkembang lebih masif untuk memperluas dampaknya di masyarakat, kegiatan sosialisasi secara luar jaringan juga dilakukan secara rutin dengan cara yang lebih menarik, terstruktur dan bekerjasama dengan berbagai stakeholder, seharusnya dalam pengembangan platform ini tidak hanya untuk generasi Milenial dan Zilenial tetapi sosialisasi ini juga harus membidik generasi $X$ sebagai generasi muda yang akan menjadi penerus edukasi dengan penyandang disabilitas. Selain itu, program ini dapat kurang dikampanyekan dengan Instagram ads dan tidak menggait banyak influencers sehingga hanya sedikit masyarakat yang terjaring edukasi melalui Sapardi id, dalam implementasinya hanya kelompok kecil disekitar Jawa Barat yang mendapat pengetahuan tentang bagaimana cara berkomunikasi dengan penyandang disabilitas dan membuat karya ramah disabilitas melalui Sapardi id padahal tujuan utama platform ini adalah menciptakan banyak generasi muda Indonesia yang dapat berkomunikasi dengan penyandang disabilitas agar penyandang disabilitas dapat lebih leluasa mencari informasi dalam bersosialisasi dengan masyarakat luas sehingga kemampuannya menjadi lebih berkembang dalam menghadapi revolusi industri 4.0 .

Dengan demikian, Sapardi id memang dikatakan sudah mampu mewujudkan nilai dalam Undang-Undang Dasar 1945, UndangUndang Nomor 8 Tahun 2016 Tentang Disabilitas, Convention on the Rights of Persons with Disabilities (CRPD yang sudah diratifikasi melalui Undang Undang Nomor 19 Tahun 2011), Undang-Undang Nomor 29 Tahun 1999 tentang Pengesahan International Convention on the Elimination of All Forms of Racial Discrimination 1965 (Konvensi Internasional tentang Penghapusan Segala Bentuk Diskriminasi Rasial 1965), Undang Undang Nomor 39 Tahun 1999 tentang Hak Asasi Manusia, Undang-Undang Nomor 11 Tahun 2009 tentang Kesejahteraan Sosial, Putusan MK Nomor 10-17-23/PUU-VII/2009; Putusan MK Nomor 143/PUU-VII/2009; dan Putusan MK No. 16/PUU-VIII/2010 diharapkan pula dapat melakukan pengesahan apabila berminat menjadi komunitas dalam masyarakat, selain itu harus dapat membuka peluang untuk mengajak masyarakat yang lebih luas turut serta dalam kampanye pengenalan bahasa khusus penyandang disabilitas, programprogram Sapardi id harus dilakukan secara massif, berkelanjutan dan menggait banyak pihak agar senantiasa tetap dapat mewujudkan amanat undang-undang.

\section{REFERENSI}

Arikunto, S. (2012). Prosedur Penelitian Suatu Pendekatan Praktek. Jakarta: Rineka Cipta.

Fajar, J. (2017). Manajemen Media Massa. Yogyakarta: Buku Litera. 
Handoko, T. H. (2012). Manajemen Personalia dan Sumber Daya Manusia. Yogyakarta: BPFE.

Kementrian Sosial Republik Indonesia. (2018). Data Penyandang Disabilitas. Retrieved from kemensos.go.id

Putusan MK Nomor 10-17-23/PUU-VII/2009

Putusan MK Nomor 143/PUU-VII/2009

Putusan MK No. 16/PUU-VIII/2010

Pusdiklat Perpustakaan Nasional Republik Indonesia. (2021, Maret 03). Program Pelatihan Bahasa Isyarat. Retrieved from https://pusdiklat.perpusnas.go.id/berita/rea d/44/program-pelatihan-bahasa-isyarat

Sikula, A. F. (2015). Manajemen Sumber Daya Manusia Untuk Perusahaan Dari Teori. Ke Praktek. Jakarta: PT. Raja Grafindo Persada.

Soekanto, S., \& Mamuji, S. (2003). Penelitian Hukum Normatif Suatu Tinjauan Singkat. Jakarta: PT. Raja Grafindo Persada.

Sugiyono. (2009). Metode Penelitian (Pendekatan Kuantitatif, Kualitatif, dan $R \& D)$. Bandung: Alfabeta.
Undang Undang Nomor 8 Tahun 2016 Tentang Disabilitas

Undang-Undang Dasar 1945

Undang Undang Nomor 8 Tahun 2016 Tentang Disabilitas

Convention on the Rights of Persons with Disabilities (CRPD yang sudah diratifikasi melalui Undang Undang Nomor 19 Tahun 2011)

Undang-Undang Nomor 29 Tahun 1999 tentang Pengesahan International Convention on the Elimination of All Forms of Racial Discrimination 1965 (Konvensi Internasional tentang Penghapusan Segala Bentuk Diskriminasi Rasial 1965)

Undang Undang Nomor 39 Tahun 1999 tentang Hak Asasi Manusia

Undang-Undang Nomor 11 Tahun 2009 tentang Kesejahteraan Sosial 